\title{
Detoxification of aliphatic and aromatic organic pollutants by means of catalytic wet-air oxidation
}

\author{
A. Pintar, J. Batista \& T. Tišler \\ National Institute of Chemistry, Ljubljana, Slovenia
}

\begin{abstract}
One of the most promising options for removal of toxic and non-biodegradable organic compounds from industrial wastewaters is destruction of these contaminants by means of catalytic wet-air oxidation (CWAO). In this study, the performance of various $\mathrm{Ru} / \mathrm{TiO}_{2}$ catalysts to promote oxidation of aqueous solutions of formic acid, acetic acid and phenol was investigated in a continuousflow trickle-bed reactor. Oxidation experiments were carried out at $\mathrm{T}=328-523 \mathrm{~K}$ and total pressures up to 50 bar. Complete oxidation of formic acid was obtained at mild operating conditions $(383 \mathrm{~K})$, and no catalyst deactivation occurred that could be attributed to the dissolution of active ingredient material. Liquid-phase oxidation of recalcitrant acetic acid was found to be structure sensitive; the highest catalyst activity was obtained when the $\mathrm{Ru}$ phase on the catalyst surface prevailed in the zero-valent oxidation state. The employed $\mathrm{Ru} / \mathrm{TiO}_{2}$ catalysts enable complete removal of phenol and more than $99 \%$ removal of TOC at temperatures above $483 \mathrm{~K}$; at these conditions, no carbonaceous deposits were accumulated on the catalyst surface. In the presence of a $\mathrm{Ru} / \mathrm{TiO}_{2}$ catalyst in the trickle-bed reactor, the toxicity to Daphnia magna and Vibrio fischeri of the oxidized materials was greatly reduced compared with that of the starting solutions. However, despite the notable decrease in toxicity, end-product solutions are generally more toxic than indicated by the concentrations of total organic carbon remaining in the final solutions.
\end{abstract}

Keywords: acute toxicity tests, catalytic wet-air oxidation, heterogeneous catalysis, ruthenium catalysts, titanium oxide, trickle-bed reactor, wastewater treatment. 


\section{Introduction}

Considering the need for environmental protection, one of the promising options for removal of toxic and non-biodegradable organic compounds from industrial wastewaters is destruction of these contaminants by catalytic wet-air oxidation (CWAO) [1]. In the CWAO process, schematically illustrated in fig. 1, the organic pollutants are oxidized by activated $\mathrm{O}_{2}$ species in the presence of a solid catalyst, usually at temperatures of 403-523 K and pressures of 10-50 bar, into biodegradable intermediate products or mineralized into $\mathrm{CO}_{2}$, water and associated inorganic salts. The CWAO of various organic compounds has been studied over metal oxides, mixed metal oxide systems and noble metal catalysts [2]. Titania and zirconia supported $\mathrm{Ru}$ catalysts have received much attention recently, because they exhibited high activity and chemical resistance in CWAO of different model pollutants [3-5] and industrial wastewaters [6, 7].

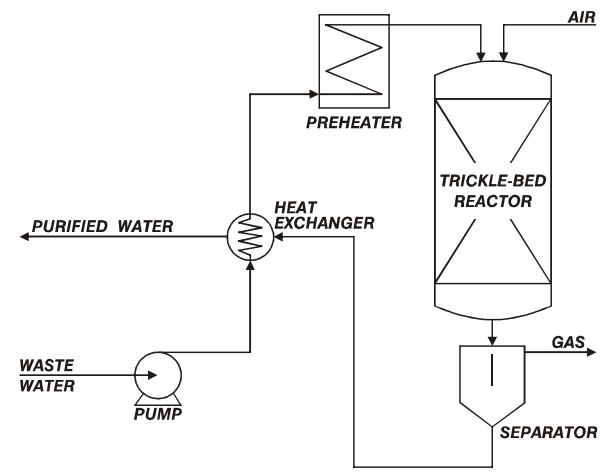

Figure 1: Schematic drawing of a simple process for catalytic wet-air oxidation.

Acetic acid is a refractory intermediate typically produced in the oxidation route of various organic oxygenated compounds including phenol [8]. During the wet-air oxidation of phenol in a continuous-flow bubble-column reactor packed with a pelletized $\mathrm{Ru} / \mathrm{ZrO}_{2}-\mathrm{TiO}_{2}$ catalyst, maleic acid, acetic acid and formic acid were identified as the main reaction intermediates [9]. Supported $\mathrm{Ru}$ catalysts exhibit good activity for CWAO of acetic acid to $\mathrm{CO}_{2}[3,10]$.

In this work, $\mathrm{Ru} / \mathrm{TiO}_{2}$ catalysts were prepared by incipient-wetness impregnation method and tested for CWAO of formic acid, acetic acid and phenol in a continuous-flow trickle-bed reactor operating in a wide range of reaction conditions. CWAO of formic acid was investigated in this study, because little information regarding the oxidation of this compound is available. CWAO of phenol was carried out to investigate a potential of employed catalysts for effective removal of the parent molecule and intermediates from the liquid phase, without a noticeable accumulation of carbonaceous species on the catalyst surface. The acute toxicity to Daphnia magna and Vibrio fischeri of feed and treated solutions, given as global efficiencies of $\mathrm{Ru} / \mathrm{TiO}_{2}$ catalysts for degradation and detoxification of model pollutants in water, are reported. 


\section{Experimental}

The catalysts containing 1.5 and 3.0 wt. \% of $\mathrm{Ru}$ were prepared by incipientwetness impregnation of $\mathrm{TiO}_{2}$ extrudates (Degussa-Hüls, Aerolyst type, $\mathrm{d}_{\mathrm{p}}: 1.4$ $\mathrm{mm}$ ) with an aqueous solution of $\mathrm{RuCl}_{3}$. The obtained precursors were dried and reduced for $1 \mathrm{~h}$ in $\mathrm{H}_{2}$ atmosphere at $573 \mathrm{~K}$. Textural properties of synthesized catalysts are listed in table 1.

CWAO of aqueous solutions of formic acid, acetic acid and phenol (feed concentration up to $2.0 \mathrm{~g} / \mathrm{l}$ ) by using pure $\mathrm{O}_{2}$ or air was carried out in a computer-controlled continuous-flow trickle-bed reactor system (PID Eng\&Tech, model MA-Ref). The reactor operated in the low-interaction trickleflow regime at $\mathrm{T}=328-523 \mathrm{~K}$ and $\mathrm{P}_{\text {tot. }}=10-50$ bar; the residence time of the liquid phase in the catalytic bed $(3.0 \mathrm{~g})$ was in the range from 0.12 to $0.33 \mathrm{~min}$. Representative liquid-phase samples, continuously collected from the reactor unit, were analyzed by means of HPLC and total organic carbon (TOC) analyses.

Table 1: $\quad$ Textural and physicochemical properties of catalysts.

\begin{tabular}{|c|c|c|c|c|c|c|}
\hline Catalyst & $\begin{array}{c}\text { Run } \\
\text { no. }\end{array}$ & $\begin{array}{l}\text { Model } \\
\text { pollutant }\end{array}$ & $\begin{array}{l}\mathrm{S}_{\mathrm{BET}}, \\
\mathrm{m}^{2} / \mathrm{g}\end{array}$ & $\begin{array}{l}V_{\text {pore }}, \\
\mathrm{cm}^{3} / \mathrm{g}\end{array}$ & $\begin{array}{c}\mathrm{d}_{\text {pore }}, \\
\AA\end{array}$ & $\begin{array}{l}{ }^{\mathrm{b}} \mathrm{TC}, \\
\mu \mathrm{g} / \mathrm{g}\end{array}$ \\
\hline \multirow[t]{2}{*}{$\mathrm{TiO}_{2}$} & fresh & - & 51 & 0.364 & 282 & 228 \\
\hline & $3 a$ & phenol & ${ }^{a}$ n.d. & n.d. & n.d. & 104 \\
\hline \multirow[t]{3}{*}{$\mathrm{Ru}(1.5$ wt. $\%) / \mathrm{TiO}_{2}$} & fresh & - & 50 & 0.355 & 285 & n.d. \\
\hline & 7 & acetic acid & 41 & 0.342 & 337 & 147 \\
\hline & 10 & phenol & 44 & 0.347 & 314 & 197 \\
\hline \multirow[t]{4}{*}{$\mathrm{Ru}(3.0$ wt. $\%) / \mathrm{TiO}_{2}$} & fresh & - & 50 & 0.344 & 274 & n.d. \\
\hline & 5 & formic acid & 54 & 0.345 & 255 & ${ }^{c} 3494$ \\
\hline & 8 & acetic acid & 42 & 0.343 & 326 & 113 \\
\hline & 11 & phenol & 43 & 0.340 & 316 & 100 \\
\hline
\end{tabular}

${ }^{a}$ Not determined. ${ }^{b}$ Total carbon content. ${ }^{c}$ No rinsing of catalyst sample with distilled water was performed after the completion of experiment.

The acute toxicity test with the freeze-dried bacteria Vibrio fischeri NRRL-B11177 obtained from the manufacturer (Dr. Lange GmbH, Düsseldorf, Germany) was performed according to the ISO standard [11]. The luminescence was measured on a LUMIStox 300 luminometer. The luminescent bacteria were exposed to different concentrations of feed sample and treated samples for 30 min at $288 \pm 0.2 \mathrm{~K}$ and the percentage of inhibition was calculated for each concentration relative to the control. In each experiment eight concentrations and a control in two replicates were tested. The 30-min $\mathrm{IC}_{50}$ values with corresponding 95\% confidence limits were calculated using a standard log-linear model supported by computer software [12]. Daphnia magna Straus 1820 (Institut für Wasser, Boden und Lufthygiene des Umweltbundesamtes, Berlin, Germany) were cultured in a temperature-controlled room at $294 \pm 1 \mathrm{~K}$ in $3-\mathrm{L}$ aquariums covered with glass plates containing $2.5 \mathrm{~L}$ of modified M4 medium [13], illuminated with fluorescent bulbs (approx. $1800 \mathrm{lux}$ ) for $12 \mathrm{~h}$ per day. They were fed daily a diet of the green alga Desmodesmus subspicatus Chodat 
1926 corresponding to $0.13 \mathrm{mg}$ carbon/daphnia. One day before the start of the experiments reproductive daphnids were isolated and young neonates (aged about $24 \mathrm{~h}$ ) were used. In the acute toxicity tests, daphnids were exposed to different concentrations of feed sample and treated samples and the immobile daphnids were counted after the $24 \mathrm{~h}$ and $48 \mathrm{~h}$ of exposure [14]. In each definitive toxicity experiment five concentrations and a control in two replicates were tested. The 24-h and 48-h $\mathrm{EC}_{50}$ values with corresponding $95 \%$ confidence limits were obtained using probit analysis [15].

\section{Results and discussion}

\subsection{CWAO of model pollutants}

Fig. 2 shows the results of $\mathrm{CWAO}$ of $\mathrm{HCOOH}$ in the presence of various $\mathrm{Ru} / \mathrm{TiO}_{2}$ catalysts. It is seen that in both cases complete oxidation of model pollutant is obtained at mild operating conditions, and that no catalyst deactivation occurs that could be attributed to the dissolution of active ingredient material. It was found out by thorough TPR/TPO examination of fresh and spent catalyst samples that in parallel to $\mathrm{HCOOH}$ oxidation, oxidation of metallic $\mathrm{Ru}$ clusters on the catalyst surface to $\mathrm{RuO}_{2}$ takes place in the given range of operating conditions. However, the nature of $\mathrm{Ru}$ active phase (being either in the metallic or oxidized state) has no influence on measured conversions of formic acid. It was further observed that besides oxidation route thermal decomposition contributes significantly to the removal of formic acid; $\mathrm{Ru} / \mathrm{TiO}_{2}$ catalysts could be thus efficiently used for transformation of $\mathrm{HCOOH}$ to $\mathrm{H}_{2}$ and $\mathrm{CO}_{2}$.

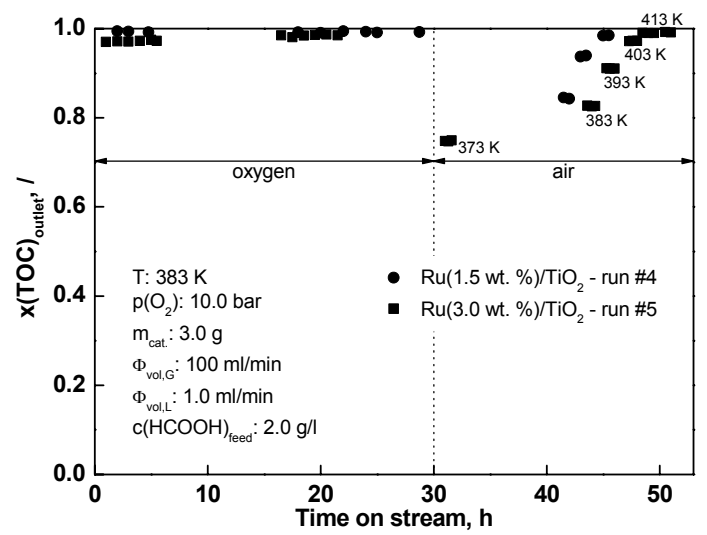

Figure 2: $\quad$ TOC conversion as a function of time on stream measured during $\mathrm{HCOOH}$ oxidation over various $\mathrm{Ru} / \mathrm{TiO}_{2}$ catalysts.

On the contrary to the above, much higher temperatures are required for deep oxidation of acetic acid. Complete removal of this pollutant was obtained at $\mathrm{T}=503 \mathrm{~K}$ and above (fig. 3). Furthermore, CWAO of acetic acid was found to be structure sensitive. The highest catalyst activity was measured at the beginning 


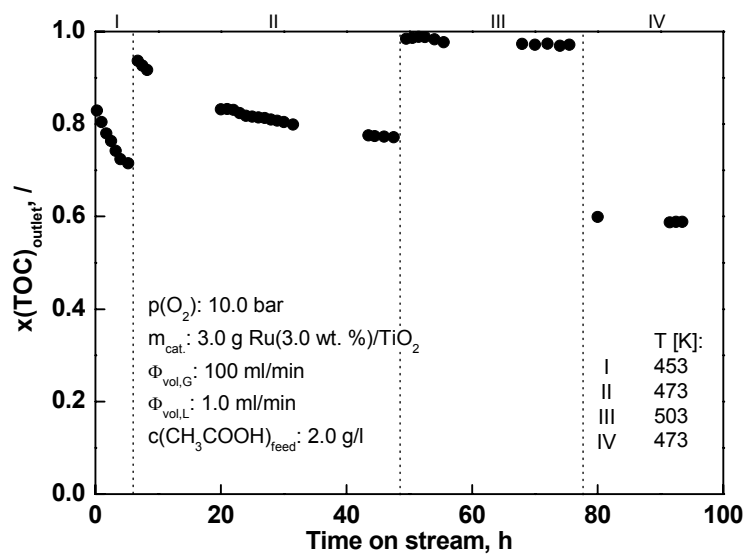

Figure 3: TOC conversion as a function of time on stream during the oxidation of acetic acid (run \#8).

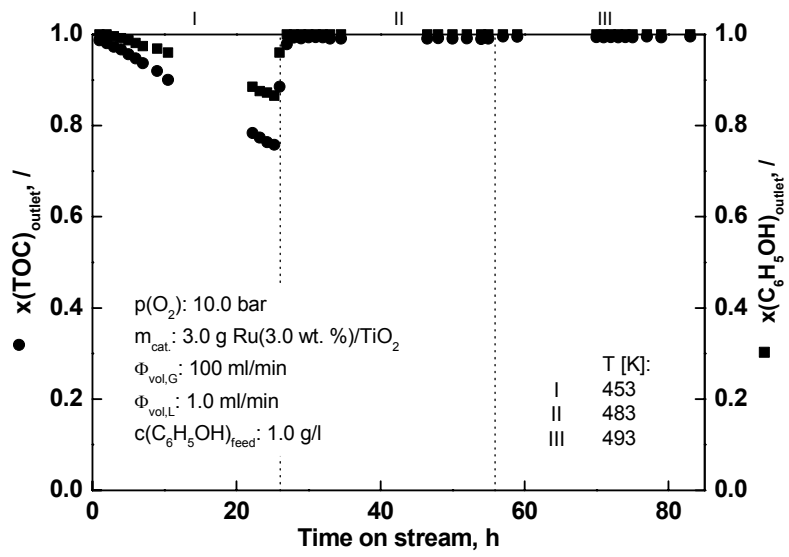

Figure 4: Phenol and TOC conversion as a function of time on stream (run \#11).

of oxidation run, when $\mathrm{Ru}$ phase on the catalyst surface prevailed in zero-valent state. Due to simultaneous oxidation of metallic $\mathrm{Ru}$ to $\mathrm{RuO}_{2}$ during the reaction course (the extent of oxidation is a function of temperature and $\mathrm{p}\left(\mathrm{O}_{2}\right)$ ), non steady-state operation was observed and correspondingly lower conversion of acetic acid was measured in the reactor outlet (fig. 3). This is in agreement with the results of another investigation [16].

Fig. 4 illustrates that the employed $\mathrm{Ru}\left(3.0\right.$ wt. \%)/ $\mathrm{TiO}_{2}$ catalyst enables complete removal of phenol and TOC at temperatures above $483 \mathrm{~K}$. At these conditions, no carbonaceous deposits were accumulated on the catalyst surface (table 1). Apparent catalyst deactivation observed at $\mathrm{T}=453 \mathrm{~K}$ (fig. 4, range I) is attributed to strong adsorption of partially oxidized intermediates (i.e. hydroquinones, benzoquinones) on the catalyst surface, which can be avoided by 
conducting the CWAO process at sufficiently high temperatures (above $473 \mathrm{~K}$ in this particular case). Due to low accumulation of intermediate acetic acid in the liquid phase, over-oxidation of $\mathrm{Ru}$ phase on the catalyst surface has negligible effect on oxidative phenol destruction.

\subsection{Acute toxicity of solutions}

\subsubsection{Formic acid and acetic acid}

Toxicity curves of feed solutions (formic acid, acetic acid) and end-product solutions after the $\mathrm{CWAO}$ process, and corresponding $\mathrm{IC}_{50}$ and $\mathrm{EC}_{50}$ values are given in fig. 5 and table 2.

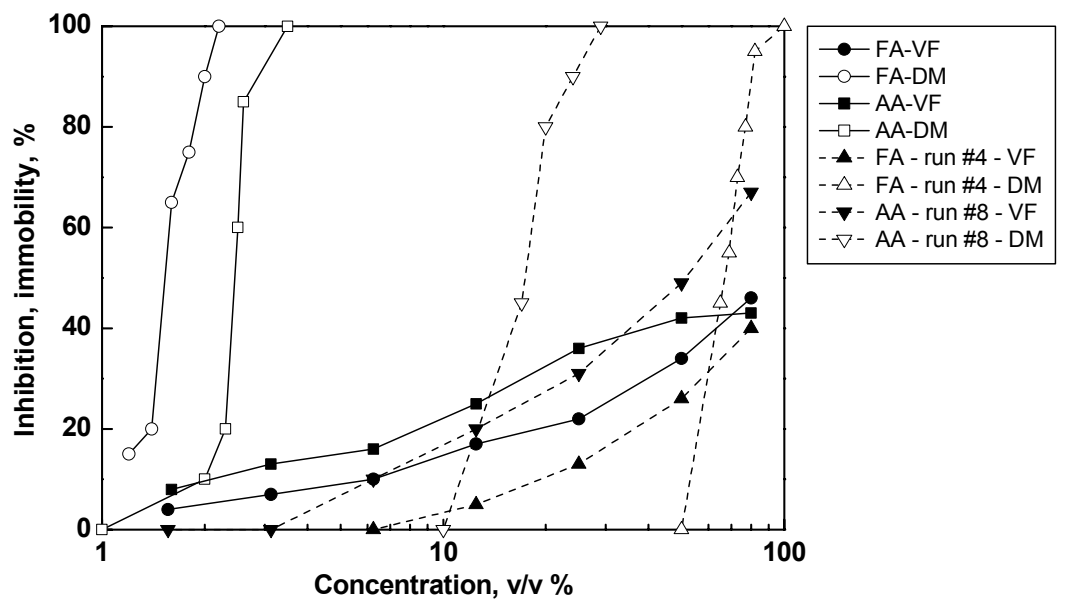

Figure 5: $\quad$ Toxicity of formic acid (FA), acetic acid (AA) and end-product samples to Vibrio fischeri (VF) and Daphnia magna (DM).

The toxicity observed for formic and acetic acid was significantly lower to bacteria than to water fleas probably due to the neutralization of the samples before the luminescence was measured. In the case of adjusted $\mathrm{pH}$ samples, $43 \%$ (formic acid) and 46\% inhibition (acetic acid) was measured in the samples with the highest tested concentration $(80 \mathrm{v} / \mathrm{v} \%)$, but the $30-\mathrm{min} \mathrm{IC}_{50}$ values were found to be $11.3 \mathrm{v} / \mathrm{v} \%$ and $13.6 \mathrm{v} / \mathrm{v} \%$ for formic and acetic acid with unchanged $\mathrm{pH}$, respectively. The light emission of luminescence bacteria is $\mathrm{pH}$ dependent [17]. In the toxicity tests with water fleas the samples with original $\mathrm{pH}$ values were tested as the $\mathrm{pH}$ of tested diluted samples were in the acceptable range for Daphnia magna. The reported 48-h $\mathrm{EC}_{50}$ values for formic acid ranged from $34.2 \mathrm{mg} / 1$ to $151 \mathrm{mg} / \mathrm{l}$ [18-20]. Keen and Baillod [18] found the 48-h $\mathrm{EC}_{50}$ to be at $47 \mathrm{mg} / \mathrm{l}$ of acetic acid, which is similar to our results.

The oxidized sample of formic acid (run \#4) was slightly less toxic than the feed solution as the toxicity threshold $\left(30-\mathrm{min} \mathrm{IC}_{20}\right)$ was found to be at 17.5 $\mathrm{v} / \mathrm{v} \%$ (feed solution) and $38.4 \mathrm{v} / \mathrm{v} \%$ (run \#4). Contrary, the sample (run \#8) indicated even higher toxicity in regard to the $30-\mathrm{min} \mathrm{IC}_{50}$ of feed solution. 
However, the toxic potential of feed solutions to water fleas was significantly reduced after the CWAO experiments with $\mathrm{Ru} / \mathrm{TiO}_{2}$; the toxicity was reduced 42 times in a case of formic acid and 7 times for acetic acid.

Table 2: Summary data on toxicity of feed solutions and end-product samples after CWAO treatment.

\begin{tabular}{|c|c|c|c|c|c|c|}
\hline \multirow{2}{*}{ Sample/run } & \multirow{2}{*}{$\begin{array}{l}\text { Phenol } \\
(1.0 \mathrm{~g} / \mathrm{l}) \\
\end{array}$} & \multicolumn{3}{|c|}{$3 \mathbf{a}$} & \multicolumn{2}{|c|}{11} \\
\hline & & $(493 \mathrm{~K})$ & \multicolumn{2}{|c|}{$(513 \mathrm{~K})$} & $(483 \mathrm{~K})$ & $(493 \mathrm{~K})$ \\
\hline $\begin{array}{l}\text { V. fischeri } \\
\text { 30-min } \quad \mathrm{IC}_{50} \\
(\mathrm{v} / \mathrm{v} \%)\end{array}$ & 2.9 & 1.8 & \multicolumn{2}{|c|}{1.8} & 22.3 & 61.1 \\
\hline $95 \% \mathrm{CL}$ & $2.9-3.0$ & $1.6-1.9$ & \multicolumn{2}{|c|}{$1.7-2.0$} & $22.2-22.4$ & $60.9-61.3$ \\
\hline $\begin{array}{l}\text { D. magna } \\
48-\mathrm{h} \mathrm{EC}_{50} \\
(\mathrm{v} / \mathrm{v} \%)\end{array}$ & 0.42 & 1.1 & \multicolumn{2}{|c|}{1.5} & 18.5 & 21.6 \\
\hline $95 \% \mathrm{CL}$ & $0.31-0.57$ & $0.87-1.3$ & & & $16.7-21.6$ & $19.2-23.6$ \\
\hline Sample/run & $\begin{array}{c}\text { Formic acid } \\
(2.0 \mathrm{~g} / \mathrm{l})\end{array}$ & \multicolumn{2}{|c|}{$\begin{array}{c}\mathbf{4} \\
(383 \mathrm{~K})\end{array}$} & \multicolumn{2}{|c|}{$\begin{array}{c}\text { Acetic acid } \\
(2.0 \mathrm{~g} / 1)\end{array}$} & $\begin{array}{c}\mathbf{8} \\
(503 \mathrm{~K})\end{array}$ \\
\hline $\begin{array}{l}\text { V. fischeri } \\
\text { 30-min } \mathrm{IC}_{50} \\
(\mathrm{v} / \mathrm{v} \%) \\
95 \% \mathrm{CL}\end{array}$ & n.d. & \multicolumn{3}{|c|}{ n.d. } & n.d. & $\begin{array}{c}46.9 \\
46.7-47.0\end{array}$ \\
\hline \multirow{2}{*}{$\begin{array}{l}\text { D. magna } \\
48-\mathrm{ECC}_{50} \\
(\mathrm{v} / \mathrm{v} \%) \\
95 \% \mathrm{CL}\end{array}$} & 1.6 & \multirow{2}{*}{\multicolumn{2}{|c|}{67.1}} & & 2.4 & 17.2 \\
\hline & $1.5-1.6$ & & & & $3-2.5$ & $13.2-18.7$ \\
\hline
\end{tabular}

\subsubsection{Phenol}

Toxicity curves of phenol feed solution and end-product solutions after CWAO treatment, and corresponding $\mathrm{IC}_{50}$ and $\mathrm{EC}_{50}$ values are given in fig. 6 and table 2 .

Toxicity of feed solution was higher to water fleas $\left(48-\mathrm{h} \mathrm{EC}_{50}=0.42 \mathrm{v} / \mathrm{v} \%\right)$ than to bacteria $\left(30-\min \mathrm{EC}_{50}=2.9 \mathrm{v} / \mathrm{v} \%\right)$. The obtained results match the literature data on phenol toxicity. The acute toxicity of phenol to water fleas is well documented; the reported $48-\mathrm{h} \mathrm{EC}_{50}$ values ranged from 4.2 to $30 \mathrm{mg} / \mathrm{l}$ based on daphnids immobility $[18,21,22]$. The published $\mathrm{IC}_{50}$ values in the case of Vibrio fischeri are between 22.0 and $40.2 \mathrm{mg} / 1$ [22, 23].

After the phenol oxidation in the presence of $\mathrm{TiO}_{2}$ the toxicity slightly increased to Vibrio fischeri comparing the 30-min $\mathrm{IC}_{20}$ and $\mathrm{IC}_{50}$ values, probably due to production of toxic intermediates. Different temperatures (runs \#3a) used in the oxidation processes did not significantly alter the toxicity. Contrary to the response of bacteria, the toxicity to water fleas declined after the oxidation using $\mathrm{TiO}_{2}$; higher temperature used in the experiment reduced the toxicity more evidently (runs \#3a). However, the obtained toxicity test results clearly indicate that the oxidation process in the presence of $\mathrm{Ru} / \mathrm{TiO}_{2}$ was very effective in removal of feed sample toxicity to both tested organisms. The toxicity was 


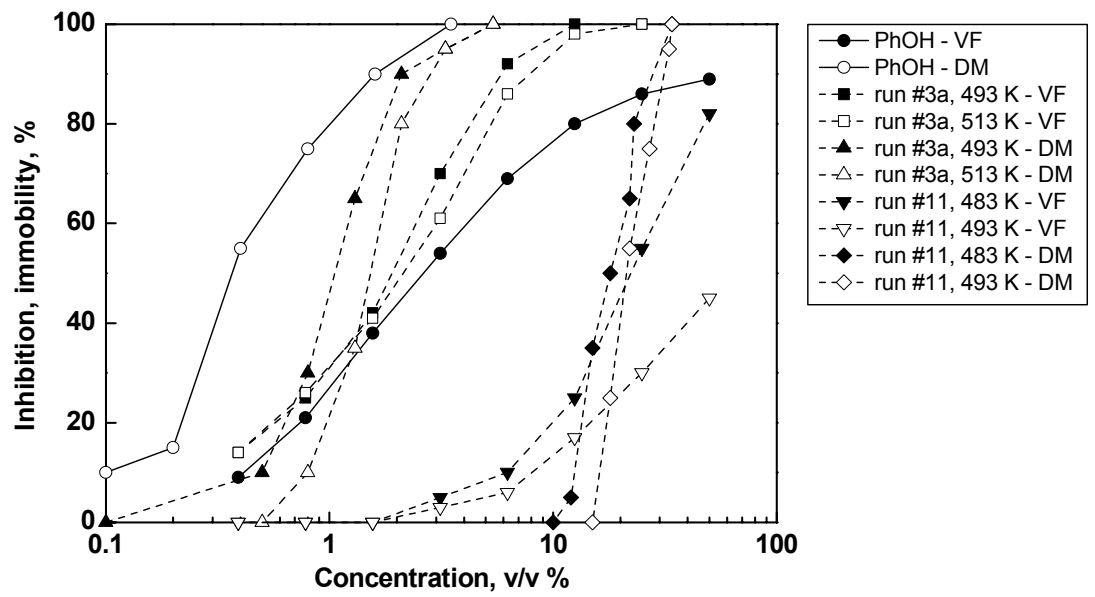

Figure 6: Toxicity of phenol $(\mathrm{PhOH})$ feed solution and end-product samples to Vibrio fischeri (VF) and Daphnia magna (DM).

reduced for 44 and 51 times comparing the 48-h $\mathrm{EC}_{50}$ values of feed solution and end-product solutions to water fleas in the presence of $\mathrm{Ru}(3.0 \mathrm{wt}$. $\%) / \mathrm{TiO}_{2}$ catalyst at different temperatures (runs \#11).

To conclude, $\mathrm{CWAO}$ using $\mathrm{Ru} / \mathrm{TiO}_{2}$ catalysts was very effective in removing the toxicity from the feed samples as toxicity significantly decreased in end products samples in comparison to the initial toxicity. Although lower toxicity was measured in the treated samples, it is evidently that some compounds toxic to aquatic organisms still remain in the samples. The obtained results clearly demonstrate that an application of analytical measurements and toxicity tests using aquatic organisms is of crucial importance for a reliable assessment of samples quality before discharging the effluents into aquatic environment.

\section{Conclusions}

The reaction temperature, chemical potentials of reactants and residence time affect the activity of catalysts and toxicity of effluents resulting from CWAO of aqueous solutions of formic acid, acetic acid and phenol. $\mathrm{Ru}\left(1.5 \mathrm{wt}\right.$. \%)/ $/ \mathrm{TiO}_{2}$ and $\mathrm{Ru}\left(3.0\right.$ wt. \%)/ $\mathrm{TiO}_{2}$ catalysts yielded complete removal of formic acid at $\mathrm{T}=383$ $\mathrm{K}$. Formation of partially oxidized $\mathrm{Ru}$ surface layer during the $\mathrm{CWAO}$ of formic acid seems not to affect the catalyst activity. $\mathrm{Ru} / \mathrm{TiO}_{2}$ promotes thermally induced decarboxylation of formic acid. The results of catalytic tests coupled with the physicochemical characterization of used catalysts after CWAO of acetic acid reveal that the decrease of catalytic activity is due to partial oxidation of metallic $\mathrm{Ru}$ particles to $\mathrm{RuO}_{2}$. The amounts of $\mathrm{RuO}_{2}$ and $\mathrm{Ru}^{0}$ depend on reaction temperature and concentration of liquid-dissolved $\mathrm{O}_{2}$. Over 95\% TOC reduction could be achieved in the presence of $\mathrm{Ru}(3.0 \mathrm{wt} . \%) / \mathrm{TiO}_{2}$ catalyst at $\mathrm{T}=503 \mathrm{~K}, 10.0$ bar of oxygen and residence time of $0.14 \mathrm{~min}$. $\mathrm{Ru} / \mathrm{TiO}_{2}$ catalysts 
are active for total conversion of phenol in aqueous solution at $\mathrm{T} \geq 483 \mathrm{~K}$. The TOC abatement is greater than $99 \%$; the rest of carbon is found in the form of acetic acid. At lower reaction temperatures, adsorption of partially oxidized C-6 intermediates occurs, which results in apparent catalyst deactivation. This can be avoided by conducting the CWAO process at sufficiently high temperatures, which facilitate desorption of intermediates and their transformation to $\mathrm{CO}_{2}$.

In the presence of $\mathrm{Ru} / \mathrm{TiO}_{2}$ catalysts, the acute toxicity to Daphnia magna and Vibrio fischeri of the oxidized materials was greatly reduced compared with that of the feed solutions. However, end-product solutions are generally more toxic than indicated by the concentrations of total organic carbon remaining in the reactor outlet streams. Before discharging them to the environment, evaluations of the residual toxicity should be performed that are based on actual bioassays, and not only on the potential of the CWAO process for destroying the original material entering the process.

\section{References}

[1] Luck, F., Wet air oxidation: past, present and future. Catalysis Today, 53, pp. 81-91, 1999.

[2] Cybulski, A., Catalytic wet air oxidation: Are monolithic catalysts and reactors feasible? Industrial \& Engineering Chemistry Research, 46, pp. 4007-4033, 2007.

[3] Duprez, D., Delanoë, F., Barbier Jr., J., Isnard, P. \& Blanchard, G., Catalytic oxidation of organic compounds in aqueous media. Catalysis Today, 29, pp. 317-322, 1996.

[4] Kojima, Y., Fukuta, T., Yamada, T., Onyango, M.S., Bernardo, E.C., Matsuda, H. \& Yagishita, K., Catalytic wet oxidation of $o$-chlorophenol at mild temperatures under alkaline conditions. Water Research, 39, pp. 29 $36,2005$.

[5] Li, N., Descorme, C. \& Besson, M., Catalytic wet air oxidation of aqueous solution of 2-chlorophenol over Ru/zirconia catalysts. Applied Catalysis B: Environmental, 71, pp. 262-270, 2007.

[6] Pintar, A., Besson, M. \& Gallezot, P., Catalytic wet air oxidation of Kraft bleaching plant effluents in the presence of titania and zirconia supported ruthenium. Applied Catalysis B: Environmental, 30, pp. 123-139, 2001.

[7] Pintar, A., Besson, M. \& Gallezot, P., Catalytic wet air oxidation of Kraft bleach plant effluents in a trickle-bed reactor over a $\mathrm{Ru} / \mathrm{TiO}_{2}$ catalyst. Applied Catalysis B: Environmental, 31, pp. 275-290, 2001.

[8] Levec, J. \& Pintar, A., Catalytic oxidation of aqueous solutions of organics. An effective method for removal of toxic pollutants from waste waters. Catalysis Today, 24, pp. 51-58, 1995.

[9] Wang, J., Zhu, W., Yang, S., Wang, W. \& Zhou, Y., Catalytic wet air oxidation of phenol with pelletized ruthenium catalysts. Applied Catalysis B: Environmental, 78, pp. 30-37, 2007.

[10] Mikulová, J., Rossignol, S., Barbier Jr., J., Mesnard, D., Kappenstein, C. \& Duprez, D., Ruthenium and platinum catalysts supported on $\mathrm{Ce}, \mathrm{Zr}, \mathrm{Pr}-\mathrm{O}$ 
mixed oxides prepared by soft chemistry for acetic acid wet air oxidation. Applied Catalysis B: Environmental, 72, pp. 1-10, 2007.

[11] Water quality - Determination of the inhibitory effect of water samples on the light emission of Vibrio fischeri (Luminescent bacteria test) - Part 2: Method using liquid-dried bacteria. ISO Standard No. 11348-2. ISO, Geneve, 1998.

[12] Dr. Lange LUMISsoft 4 software, Version 1.001, Düsseldorf, 2000.

[13] Kühn, R., Pattard, M., Pernack, K.D. \& Winter, A., Results of the harmful effects of water pollutants to Daphnia magna in the 21 day reproduction test. Water Research, 23, pp. 501-510, 1984.

[14] Water quality - Determination of the inhibition of the mobility of Daphnia magna Straus (Cladocera, Crustacea). ISO Standard No. 6341. ISO, Geneva, 1996.

[15] US Environmental Protection Agency toxicity data analysis software. EPA, Environmental Monitoring Systems Laboratory, Cincinnati (OH), 1994.

[16] Pham Minh, D., Gallezot, P. \& Besson, M., Treatment of olive oil mill wastewater by catalytic wet air oxidation: 3. Stability of supported ruthenium catalysts during oxidation of model pollutant $p$-hydroxybenzoic acid in batch and continuous reactors. Applied Catalysis B: Environmental, 75, pp. 71-77, 2007.

[17] Tišler, T. \& Zagorc-Končan, J., The »whole-effluent« toxicity approach. International Journal of Environment and Pollution, 31, pp. 3-11, 2007.

[18] Keen, R. \& Baillod, C.R., Toxicity to Daphnia of the end products of wet oxidation of phenol and substituted phenols. Water Research, 19, pp. 767$772,1985$.

[19] Randall, T.L. \& Knopp, P.V., Detoxification of specific organic substances by wet oxidation. Journal of Water Pollution Control Federation, 52, pp. 2117-2130, 1980.

[20] Formic acid (MSDS), www.piercenet.com/files/EN1262.pdf

[21] Toxicity studies for phenol on zooplankton; PAN Pesticide Database. www.pesticideinfo.org/List_AquireAll.jsp?Rec_Id=PC35056\&Taxa_Group =Zooplankton

[22] Toussaint, M.W., Shedd, T.R., van der Schalie, W.H. \& Leather, G.R., A comparison of standard acute toxicity tests with rapid-screening toxicity tests. Environmental Toxicology and Chemistry, 14, pp. 907-915, 1995.

[23] Kaiser, K.L.E. \& Ribo, J.M., Photobacterium phosphoreum toxicity bioassay. II. Toxicity data compilation. Toxicity Assessment, 3, pp. 195$237,1988$. 